\title{
Increase in skeletal muscle protein content by the B-2 selective adrenergic agonist clenbuterol exacerbates hypoalbuminemia in rats fed a low-protein diet
}

\section{A.L. Sawaya ${ }^{1}$ and P.G. Lunn²}

\author{
'Disciplina de Neurofisiologia e Fisiologia Endócrina, \\ Departamento de Fisiologia, Universidade Federal de São Paulo, \\ São Paulo, SP, Brasil \\ ${ }^{2}$ Dunn Nutritional Laboratory, Cambridge, UK
}

\section{Correspondence \\ A.L. Sawaya \\ Disciplina de Neurofisiologia e \\ Fisiologia Endócrina \\ Departamento de Fisiologia \\ Universidade Federal de São Paulo \\ Rua Botucatu, 862 \\ Ed. Biomédicas, $2^{\circ}$ andar \\ 04023-060 São Paulo, SP \\ Brasil \\ Fax: 55 (011) 872-8631 \\ E-mail: ana.fisi@epm.br}

Research supported by CNPq and Dunn Nutrition Fund.

Publication supported by FAPESP. $\ldots \ldots \ldots \ldots \ldots \ldots \ldots \ldots \ldots \ldots$

Received June 13, 1997 Accepted February 26, 1998

\section{Abstract}

This investigation examined how the nutritional status of rats fed a low-protein diet was affected when the animals were treated with the ß-2 selective agonist clenbuterol (CL). Males (4 weeks old) from an inbred, specific-pathogen-free strain of hooded rats maintained at the Dunn Nutritional Laboratory were used in the experiments $(\mathrm{N}=6$ rats per group). CL treatment (Ventipulmin, Boehringer-Ingelheim Ltd., $3.2 \mathrm{mg} / \mathrm{kg}$ diet for 2 weeks) caused an exacerbation of the symptoms associated with protein deficiency in rats. Plasma albumin concentrations, already low in rats fed a low-protein diet (group A), were further reduced in $\mathrm{CL}$ rats $(\mathrm{A}=25.05 \pm 0.31$ vs $\mathrm{CL}=23.64 \pm 0.30 \mathrm{~g} / \mathrm{l}, \mathrm{P}<0.05)$. Total liver protein decreased below the level seen in either pair-fed animals (group $\mathrm{P}$ ) or animals with free access to the low-protein diet $(\mathrm{A}=736.56 \pm 26$ vs $\mathrm{CL}=535.41 \pm 54 \mathrm{mg}, \mathrm{P}<0.05)$, whereas gastrocnemius muscle protein was higher than the values normally described for control $(C)$ animals $(C=210.88 \pm 3.2$ vs $\mathrm{CL}=227.14 \pm$ $1.7 \mathrm{mg} / \mathrm{g}, \mathrm{P}<0.05)$. Clenbuterol-treated rats also showed a reduction in growth when compared to $\mathrm{P}$ rats $(\mathrm{P}=3.2 \pm 1.1$ vs $\mathrm{CL}=-10.2 \pm 1.9 \mathrm{~g}$, $\mathrm{P}<0.05)$. This was associated with a marked decrease in fat stores $(\mathrm{P}=$ $5.35 \pm 0.81$ vs $\mathrm{CL}=2.02 \pm 0.16 \mathrm{~g}, \mathrm{P}<0.05)$. Brown adipose tissue (BAT) cytochrome oxidase activity, although slightly lower than in $\mathrm{P}$ rats $(\mathrm{P}=469.96 \pm 16.20$ vs $\mathrm{CL}=414.48 \pm 11.32 \mathrm{U} / \mathrm{BAT} \times \mathrm{kg}$ body weight, $\mathrm{P}<0.05)$, was still much higher than in control rats $(\mathrm{C}=159.55$ \pm 11.54 vs $\mathrm{CL}=414.48 \pm 11.32 \mathrm{U} / \mathrm{BAT} \mathrm{x}$ kg body weight, $\mathrm{P}<0.05)$. The present findings support the hypothesis that an increased muscle protein content due to clenbuterol stimulation worsened amino acid availability to the liver and further reduced albumin synthesis causing exacerbation of hypoalbuminemia in rats fed a low-protein diet.

\section{Key words}

- Protein-energy malnutrition

- Rats

- Clenbuterol

- Hypoalbuminemia

- Brown adipose tissue

- B-2 Agonist 


\section{Introduction}

Hypoalbuminemia is a primary feature of the protein-energy malnutrition syndrome kwashiorkor. Data from balance studies have shown that for hypoalbuminemia to occur, not only has dietary protein to be inadequate, but it is also necessary for energy consumption to be in excess of requirements for the protein-limited growth rate $(1,2)$. However, the mechanisms by which an energy surplus interferes with protein metabolism remain unknown.

It is now well established that rats and other animals fed diets of low protein content become hyperphagic, but are able to dissipate much of their energy surfeit by a rise in diet-induced thermogenesis (3). In particular, a large increase in the activity of brown adipose tissue has been described (46). In keeping with this picture, one of the hormones most directly involved in energy dissipation, norepinephrine (NE), is elevated in rats fed low-protein diets $(7,8)$. Many studies (9-13) have also demonstrated an increased protein deposition and an elevation in the rate of protein synthesis in skeletal muscle when either normal rats or rats fed a low-protein diet were treated with the specific $\beta-2$ selective agonist, clenbuterol. It is therefore possible that the increase in norepinephrine levels which occurs as a metabolic consequence of excess energy intake might act to maintain skeletal muscle protein even when dietary protein intake is limited. Clearly, such a mechanism could explain the inappropriate protein distribution and hypoalbuminemia seen in protein-deficient rats $(14,15)$ and the 'dysadaptation' syndrome of kwashiorkor in children $(16,17)$.

Although studies of the effects of $\beta$-adrenergic agonists on metabolic rate and brown adipose tissue (BAT) activity have indicated that the actions of the sympathetic nervous system on BAT are mediated predominantly by $\beta$-1-type adrenoceptors, $\beta-2$ selective adrenergic agonists are also involved since a total inhibition can only be achieved by a combination of $\beta-1$ and $\beta-2$ receptor antagonists (18). In fact, like $\beta-1$ drugs, $\beta-2$ selective adrenergic agonists stimulate oxygen consumption in rats, and raise both BAT temperature and the activity of the mitochondrial proton-conductance pathway in this tissue (9).

The present report describes an attempt to produce metabolic changes which stimulate muscle protein synthesis and energy dissipation in rats fed diets of low protein content, by administration of the $B-2$ selective agonist clenbuterol. We expected that an increase in sympathetic activity would worsen the features previously reported for rats fed low-protein diets (6), and therefore cause a greater reduction in plasma albumin. This could be reasonable evidence that hypoalbuminemia is also promoted by increased B-2 selective agonist activity during consumption of low-protein diets. In addition, to have a better picture of the metabolic changes produced by the present drug treatment, two hormones, $\mathrm{T}_{3}$ and insulin, known to be associated with plasma albumin levels in rats fed a low-protein diet, were measured $(1,4,6,15)$.

\section{Material and Methods}

Males from an inbred, specific-pathogen-free strain of hooded rats maintained at the Dunn Nutritional Laboratory were used in the experiments. Animals were weaned at 3 weeks to a synthetic casein-based diet of protein energy:total energy (P:E) ratio 0.20 (Table 1) for 1 week before the experimental procedures began and then divided into 3 groups. Rats in the control group (A) were given free access to a low-protein diet (P:E 0.03 ) for 2 weeks (Table 1). In the drugtreated rats (group CL), clenbuterol hydrochloride (a specific ß-2 selective agonist, market as Ventipulmin, Boehringer-Ingelheim Ltd., London, UK) was mixed into the low-protein diet ( $3.2 \mathrm{mg} / \mathrm{kg}$ diet) for 2 weeks. A third group, receiving the control low- 
protein diet, was pair-fed with CL animals (group P).

During the experimental period the rats were individually housed in wire cages fitted with trays to collect food spillage. Ambient temperature was kept at $20-23^{\circ} \mathrm{C}$ and a $12-\mathrm{h}$ light-dark cycle was maintained. Food and water were freely available. Animals were weighed and their food consumption was recorded daily.

At the end of the experimental period, the animals were killed between 10:00 and 11:00 $\mathrm{h}$ by exsanguination under diethyl ether anesthesia. Blood was collected into heparinized tubes and the resulting plasma stored at $-20^{\circ} \mathrm{C}$ until required for analysis. Interscapular BAT was removed into ice cold SHE buffer $(0.25 \mathrm{~mol} / 1$ sucrose, $0.1 \mathrm{mmol} / 1$ HEPES, $0.1 \mathrm{~mol} / \mathrm{l}$ dipotassium EDTA, $\mathrm{pH}$ 7.2) and separated from adhering muscle and white fat. It was then blotted, weighed and homogenized and kept at $4^{\circ} \mathrm{C}$ for the assay of cytochrome oxidase activity. The liver and the gastrocnemius muscle from one leg were removed and weighed, and aliquots taken into small tin capsules for nitrogen analysis using an automated nitrogen analyzer (Dumas Analyzer, Carlo Erba, Erba Science, Swindon, UK). Protein was calculated as $\mathrm{N} \times 6.25$.

\section{Assays}

Cytochrome c oxidase (EC 1.9.3.1.) was assayed in BAT homogenates by following the oxidation of reduced cytochrome c spectrophotometrically at $550 \mathrm{~nm}$ according to the method of Yonetani and Ray (19). Plasma albumin was determined using a bromocresol green technique (6). Concentrations of $\mathrm{T}_{3}$ and insulin in plasma were measured by radioimmunoassay using reagents supplied in kit form by Amersham International (Amersham, Bucks, UK).

An estimate of the carcass composition was obtained by freeze drying the animal carcass. Body water (\%) and body fat (\%) were calculated from total body water content measured by desiccation. It was assumed that water constituted $732 \mathrm{~g} / \mathrm{kg}$ of the fat-free wet weight of the animals (20) according to the equation: $\%$ fat $=100(1-\%$ total body water $/ 0.732$. Then the percentage of fat was converted to total body fat by the equation: $\%$ fat $\mathrm{x}$ body weight $/ 100$.

Statistical differences were assessed using one-way ANOVA. Fisher's least-significant-difference test was performed subsequently for pair comparisons.

\section{Results}

No differences in food consumption were observed between the groups studied (Table 2). In spite of this, a marked reduction in weight gain was observed when rats with free access to the low-protein $\operatorname{diet}($ group A) were compared to normally fed controls (group C) (Table 2). Administration of clenbuterol to rats fed a low-protein diet reduced body weight when the results were compared with either pair-fed (group P) or

Table 1 - Composition of the control and low-protein diets given to rats.

*Containing $250 \mathrm{~g} / \mathrm{kg}$ calcium carbonate, $325 \mathrm{~g} / \mathrm{kg}$ calcium hydrogen phosphate, 185 $\mathrm{g} / \mathrm{kg}$ disodium hydrogen phosphate, $205 \mathrm{~g} / \mathrm{kg}$ potassium chloride, $4.5 \mathrm{~g} / \mathrm{kg}$ magnesium sulfate, $4.35 \mathrm{~g} / \mathrm{kg}$ ferric citrate, $0.375 \mathrm{~g} / \mathrm{kg}$ copper sulfate, $0.75 \mathrm{~g} / \mathrm{kg}$ zinc carbonate, and $0.025 \mathrm{~g} / \mathrm{kg}$ potassium iodate (commercially prepared by Arthur $\mathrm{H}$. Cox, Brighton, UK). ${ }^{* *}$ Containing $2 \mathrm{~g}$ choline chloride, $20 \mathrm{mg}$ calcium pantothenate, $3 \mathrm{mg}$ thiamine, $3 \mathrm{mg}$ pyridoxine, $3 \mathrm{mg}$ riboflavin, $25 \mathrm{mg}$ nicotinamide, $0.1 \mathrm{mg}$ biotin, and $0.05 \mathrm{mg}$ cyanocobalamin. ${ }^{* \star *}$ Each rat received weekly doses of fat-soluble vitamins in arachis oil containing $344 \mu \mathrm{g}$ retinyl acetate, $5 \mu \mathrm{g}$ ergocalciferol, $2 \mathrm{mg}$ DL-alpha-tocophenylacetate, and $0.05 \mathrm{mg}$ 2-methyl-1,4-naphthoquinone.

\begin{tabular}{lcc}
\hline Constituent $(\mathrm{g} / \mathrm{kg}$ diet) & Control & Low-protein \\
\hline Casein & 210 & 31.5 \\
Cystine & 3 & 0.45 \\
Sucrose & 355 & 444.5 \\
Starch & 355 & 444.5 \\
Corn oil & 30 & 30 \\
Salt mixture* & 50 & 50 \\
Total & 1003 & 1001 \\
B-vitamin and choline chloride mixture $(\mathrm{ml} / \mathrm{kg})^{\star *}$ & 10 & 10 \\
Fat-soluble vitamin mixture & 1 dose $/$ week & 1 dose $/$ week \\
Energy content $(\mathrm{MJ} / \mathrm{kg})$ & 16.70 & 16.70 \\
Carbohydrate $(\mathrm{g} / \mathrm{kg})$ & 701 & 879 \\
Protein $(\mathrm{g})$ & 209 & 31 \\
& &
\end{tabular}


ad libitum-fed rats (group A) (Table 2). In addition, treatment with this specific NE agonist diminished even further plasma albumin levels (group P and group A vs group $\mathrm{CL}$ ). The pair-fed group, on the other hand, showed a small but significant elevation in plasma albumin, probably due to the slight decrease in food intake in comparison to $\mathrm{A}$ rats. Plasma $T_{3}$ levels were significantly higher when rats were treated with the lowprotein diet (groups A, P and CL vs C). Drug treatment, on the other hand, did not modify the plasma $T_{3}$ levels among the groups fed the low-protein diet. No changes in plasma insulin levels were observed between the four groups (Table 2). The decrease in plasma albumin levels in rats fed the low-protein $\operatorname{diet}$ (group A) was accompanied by a marked reduction in liver weight and protein content (when expressed as mg/total liver) in comparison to control rats (Table 3). CL treatment worsened this hepatic depletion (group $\mathrm{A}$ and $\mathrm{P} v s$ group $\mathrm{CL}$ ). No differences were found in gastrocnemius weight $(\mathrm{mg} / \mathrm{kg}$ body

Table 2 - Effect of clenbuterol (CL) on food consumption, weight gain and plasma measurements.

Results are reported as means \pm SEM for 6 animals per group. Group C: Normally fed control rats; group A: low-protein with free access to food; group P: pair-fed with group $\mathrm{CL}$; group $\mathrm{CL}$ : low-protein diet $+\mathrm{Cl}$ for 2 weeks. "Values on the same row not sharing a common superscript are significantly different (ANOVA followed by Fisher's least-significant-difference test).

\begin{tabular}{lcccr}
\hline & $\mathrm{C}$ & $\mathrm{A}$ & $\mathrm{P}$ & $\mathrm{CL}$ \\
\hline $\begin{array}{l}\text { Food consumption } \\
\text { (g/day x kg body weight) }\end{array}$ & $118.9 \pm 3.2$ & $129.9 \pm 6.3$ & $117.1 \pm 9.6$ & $118.3 \pm 9.3$ \\
Weight gain $(\mathrm{g})$ & & & & \\
Plasma albumin $(\mathrm{g} / \mathrm{l})$ & $31.7 \pm 3.8^{\mathrm{a} *}$ & $4.8 \pm 1.0^{\mathrm{b}}$ & $3.2 \pm 1.1^{\mathrm{b}}$ & $-10.2 \pm 1.9^{\mathrm{c}}$ \\
Plasma T3 ( $\mathrm{gg} / \mathrm{l})$ & $1.15 \pm 0.09^{\mathrm{a}}$ & $1.56 \pm 0.02^{\mathrm{b}}$ & $1.39 \pm 0.10^{\mathrm{b}}$ & $1.47 \pm 0.60^{\mathrm{b}}$ \\
Plasma insulin (mU/l) & $16.46 \pm 4.53$ & $28.81 \pm 4.58$ & $27.82 \pm 4.99$ & $38.14 \pm 7.57$
\end{tabular}

Table 3 - Effect of clenbuterol $(\mathrm{CL})$ on liver and gastrocnemius weight and protein content.

Results are reported as means \pm SEM for 6 animals per group. Group C: Normally fed control rats; group A: low-protein with free access to food; group P: pair-fed with group $\mathrm{CL}$; group $\mathrm{CL}$ : low-protein diet $+\mathrm{Cl}$ for 2 weeks. Values on the same row not sharing a common superscript are significantly different (ANOVA followed by Fisher's least-significant-difference test).

\begin{tabular}{|c|c|c|c|c|}
\hline & C & A & $\mathrm{P}$ & $\mathrm{CL}$ \\
\hline \multicolumn{5}{|l|}{ Liver weight } \\
\hline (g) & $10.44 \pm 0.46^{a}$ & $4.47 \pm 0.29^{b}$ & $4.33 \pm 0.42^{b}$ & $2.68 \pm 0.26^{c}$ \\
\hline (g/kg body weight) & $52.02 \pm 0.99 a$ & $46.62 \pm 1.27^{a}$ & $49.13 \pm 0.79 a$ & $39.02 \pm 0.89^{b}$ \\
\hline \multicolumn{5}{|l|}{ Liver protein } \\
\hline (mg/g liver) & $121.32 \pm 3.33^{a}$ & $166.37 \pm 7.41^{b}$ & $176.41 \pm 6.10^{\mathrm{b}}$ & $199.25 \pm 3.08^{c}$ \\
\hline (mg/total liver) & $1326.61 \pm 108.96^{a}$ & $736.56 \pm 26.27^{b}$ & $784.15 \pm 64.72^{b}$ & $535.41 \pm 53.66^{c}$ \\
\hline \multicolumn{4}{|l|}{ Gastrocnemius weight } & $410 \pm 43^{b}$ \\
\hline (mg/kg body weight) & $5389 \pm 255$ & $5867 \pm 85$ & $5767 \pm 89$ & $5784 \pm 100$ \\
\hline $\begin{array}{l}\text { Gastrocnemius protein } \\
\text { (mg/g muscle) }\end{array}$ & $210.88 \pm 3.20^{a}$ & $211.78 \pm 3.05^{a}$ & $218.12 \pm 1.41^{\mathrm{a}}$ & $227.14 \pm 1.67^{b}$ \\
\hline
\end{tabular}


weight) between the four groups (Table 3). On the other hand, clenbuterol administration increased gastrocnemius muscle protein content in comparison to the other groups (C, A, and P) (Table 3). The drug treatment also led to an alteration in body composition, increasing body water and decreasing body fat content (Table 4). BAT weight and cytochrome oxidase activity, although slightly lower than in pair-fed rats (group $\mathrm{P} v s$ group $\mathrm{CL}$ ), was still much higher than control rats (group C vs group CL) (Table 4).

\section{Discussion}

It is clear from the results obtained that stimulation of the $\beta$-2-adrenergic system with clenbuterol caused an exacerbation of the symptoms associated with protein deficiency in rats. Plasma albumin concentrations, already low in rats fed the low-protein diet, were further reduced in the treated animals (6). In association with this reduction in plasma albumin, total liver protein decreased below the level seen in animals with free access to the low-protein diet, whereas gastrocnemius muscle protein was higher than the well-preserved values normally described for the animals fed the low-protein diet found by us and others (15). Moreover, most of these changes were dose dependent (results not shown), the effect being more pronounced as clenbuterol concentration in the diet increased. Clearly, the overall dysadaptation effect of the low-protein diet was increased by drug administration.

In spite of the absence of a significant difference in food intake, clenbuterol-treated rats showed a much greater reduction in growth when compared to the respective pair-fed rats. This was associated with a marked decrease in fat stores. The negative effects on growth performance clearly indicate that a substantial augmentation in the energy metabolism in general had occurred (not due to elevation of specific BAT thermogenesis), in keeping with results reported by other authors $(9,12)$. The absence of BAT thermogenesis elevation in this situation of clearly low energy efficiency can be explained since it is known that BAT thermogenic activity is stimulated mainly by $B-1$ adrenergic receptors although some stimulation of $\beta-2$ receptors does occur (18). When it is considered that, in these rats fed a lowprotein diet, BAT activity is already substantially increased it is easy to understand why this less potent stimulus action via $\beta-2$ recep-

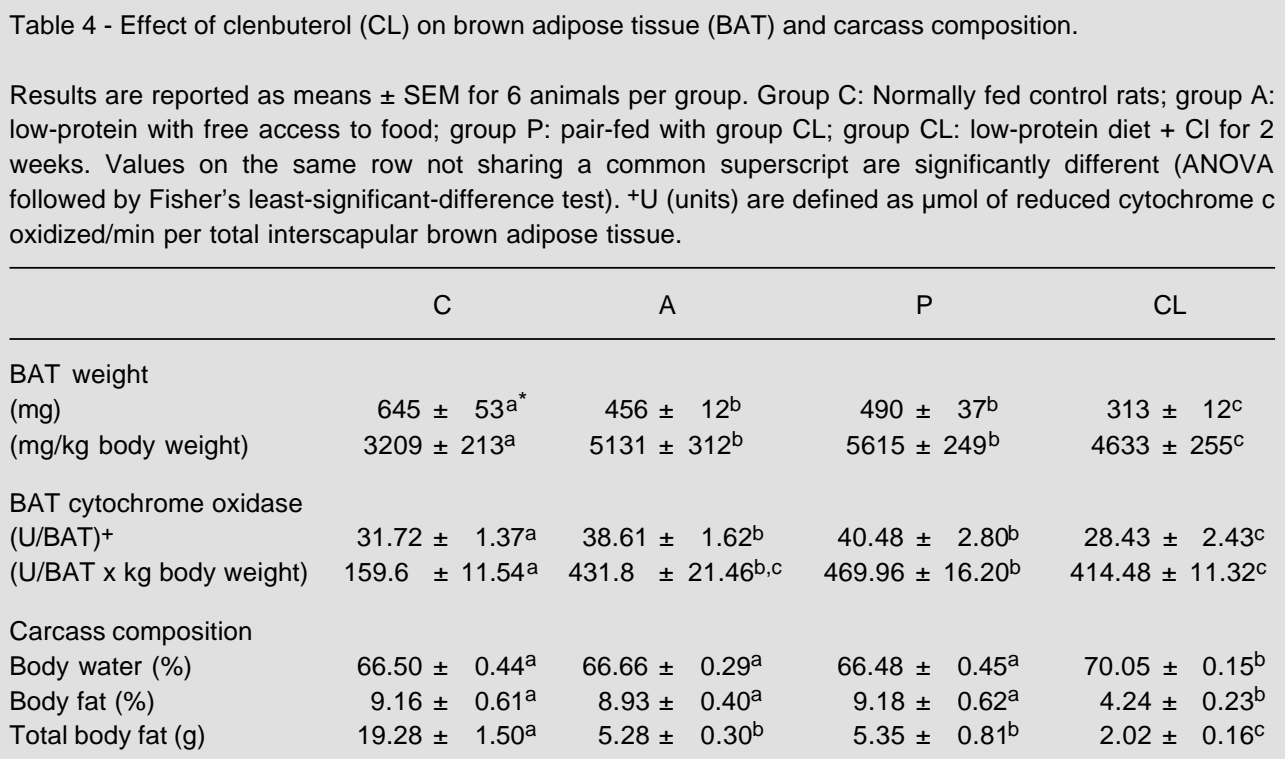


tors would fail to cause further elevation in BAT activity. In the present study, BAT cytochrome oxidase activity was in fact slightly decreased although not different from rats with free access to the low-protein diet.

On the other hand, one could argue that the reduced growth of drug-treated animals could have arisen from intestinal malabsorption of the food consumed because it is known that sympathetic stimulation promotes intestinal relaxation. If this suggestion is correct, however, treatment with CL should have caused metabolic changes such as those seen in energy-restricted animals i.e., a recovery of plasma albumin levels, a decrease of plasma total $\mathrm{T}_{3}$ values, an improvement of liver protein, etc. In fact the changes seen in CL-treated rats were the opposite of what would have been expected. Therefore it appears that the most likely explanation for the decrease in body weight and carcass fat in low-protein-CL-treated rats is a general increase in metabolic rate stimulated by this $\beta$ 2 selective agonist.

In common with other studies, our results indicate that clenbuterol increases muscle protein content associated with a decrease in liver protein content (expressed per total liver), and has a powerful lipolytic action (10-12). These observations suggest that plasma albumin synthesis was impaired by a direct B-2 adrenergic-mediated stimulation of muscle protein content. Moreover these findings corroborate the description of the metabolic dysadaptation seen in protein-deficient rats and support the suggestion that it is the better muscle preservation that probably decreases amino acid availability to the liver and, by reducing albumin synthesis, causes hypoalbuminemia.

These findings are consistent with the findings of other studies. Emery et al. (21), studying protein synthesis in liver, skeletal muscle and BAT of rats fed a $7.6 \%$ protein diet for 2 weeks, showed that there were differences in muscle and liver protein synthesis in response to this diet. In addition, they showed that there was a decrease in synthesis in both tissues but a preservation of protein mass in BAT. However, liver and muscle responded differently to the stress of protein deficiency. In the liver, the depressed protein synthesis was due to a fall (20\% lower than control) in the activity of RNA ( $\mathrm{g}$ protein synthesized $\mathrm{g} \mathrm{RNA}^{-1}$ day $^{-1}$ ) with no change in RNA content. Conversely, in skeletal muscle, RNA activity was unaltered by diet and the depressed protein synthesis could be entirely ascribed to a fall in RNA content. Similar findings were also obtained by Waterlow et al. (22) in animals fed a 3.5\% protein diet.

It is not known why these differences in liver and muscle occur. In this experimental protocol no significant differences in plasma total $\mathrm{T}_{3}$ or insulin were observed. Crowe and Royle (23) found low insulin and plasma glucose levels but increased insulin sensitivity in rats fed a low-protein diet (4\% protein) compared to a pair-fed group receiving a $14.4 \%$ protein diet. On the other hand, Sakuma et al. (2) found evidence that rats fed the $3 \%$ protein diet but with a normal energy intake presented differences in gene regulation when compared to rats fed a low-protein low-energy diet. These authors found that this nutritional condition brought about a decrease of albumin mRNA concentration both in total cytoplasmatic RNA and in poly[A]t RNA to the same extent as that of serum albumin concentration. Whichever the mechanisms involved in the regulation of liver and muscle protein synthesis in this condition of low-protein intake, the present results indicate that $\beta-2$ selective adrenergic stimulation by clenbuterol increased muscle protein and perhaps as a consequence reduced the liver amino acid availability.

In conclusion, the present findings suggest that the mechanisms that deal with muscle protein preservation in animals fed a low-protein diet, such as B-2 sympathetic activation, may also promote liver impairment and consequently hypoalbuminemia. 


\section{References}

1. Lunn P \& Austin S (1983). Excess energy intake promotes the development of hypoalbuminemia in rats fed on low-protein diets. British Journal of Nutrition, 49: 915.

2. Sakuma K, Ohyama T, Sogawa K, FujiiKuriyama Y \& Matsumura Y (1987). Low protein-high energy diet induces repressed transcription of albumin mRNA in rat liver. Journal of Nutrition, 117: 11411148.

3. Rothwell NJ, Stock MJ \& Tyzbir RS (1982). Energy balance and mitochondrial function in liver and brown fat of rats fed "cafeteria" diets of varying protein content. Journal of Nutrition, 112: 1663-1672.

4. Tyzbir RS, Kunin AS, Sims NM \& Danford Jr E (1981). Influence of diet composition on serum triiodothyronine $\left(T_{3}\right)$ concentration, hepatic mitochondrial metabolism and shuttle system activity in rats. Journal of Nutrition, 111: 252-259.

5. Rothwell NJ, Stock MJ \& Tyzbir RS (1983). Mechanisms of thermogenesis induced by low protein diets. Metabolism, 32: 257 261.

6. Sawaya AL \& Lunn PG (1985). Evidence suggesting that the elevated plasma triiodothyronine concentration of rats fed on protein deficient diets is physiologically active. British Journal of Nutrition, 53: 175-181.

7. Kenovian AV, Vander Tuig JG \& Romsos DR (1984). Consumption of a low protein diet increases norepinephrine turnover in brown adipose tissue. Journal of Nutrition, 114: 543-549.

8. Vander Tuig JG \& Romsos DR (1984).
Effects of dietary carbohydrate, fat, and protein on norepinephrine turnover in rats. Metabolism, 33: 26-33.

9. Emery PW, Rothwell NJ, Stock MJ \& Winter PD (1984). Chronic effects of $B_{2^{-}}$ adrenoceptor agonists on body composition and protein synthesis in the rat. Bioscience Reports, 4: 83-91.

10. Rothwell NJ \& Stock MJ (1987). Effect of selective beta 2-adrenergic agonist (clenbuterol) on energy balance and body composition in normal and protein deficient rats. Bioscience Reports, 7: 933940.

11. Bates PC \& Pell JM (1991). Action and interaction of growth hormone and the beta-agonist, clenbuterol, on growth, body composition and protein turnover in dwarf mice. British Journal of Nutrition, 65: 115-129.

12. Perez-Llamas F, Sastre JF \& Zamora S (1991). Influence of dietary protein level on growth: effect of clenbuterol. Comparative Biochemistry and Physiology, 99: 671-675.

13. Choo JJ, Horan MA, Little RA \& Rothwell NJ (1992). Anabolic effects of clenbuterol on skeletal muscle are mediated by $\mathrm{B}_{2}$ adrenoceptor activation. American Journal of Physiology, 263 (Endocrinology and Metabolism, 26): E50-E56.

14. Coward WA, Whitehead RG \& Lunn PG (1977). Reasons why hypoalbuminemia may or may not appear in protein-energy malnutrition. British Journal of Nutrition, 38: 115-126.

15. Lunn P \& Austin S (1983). Differences in nitrogen metabolism between protein-de- ficient and energy-deficient rats with similarly restricted growth rates. Annals of Nutrition and Metabolism, 27: 242-251.

16. Gopalan C (1968). Kwashiorkor and marasmus. Evolution and distinguishing features. In: MacCance RA \& Widdowson EM (Editors), Calorie Deficiencies and Protein Deficiencies. Churchill, London, 4958.

17. Rossouw JE (1989). Kwashiorkor in North America. American Journal of Clinical Nutrition, 49: 588-592.

18. Stribling $D$ (1983). Pharmacology of thermogenesis. In: Girardier L \& Stock M (Editors), Mammalian Thermogenesis. Chapman and Hall, London, 11: 321-354.

19. Yonetani T \& Ray GS (1965). Method for measurements of cytochrome $c$ oxidase. Journal of Biological Chemistry, 240: 3392-3398.

20. Sheng HP \& Huggins RA (1979). A review of body composition studies with emphasis on total body water and fat. American Journal of Clinical Nutrition, 32: 630-647.

21. Emery PW, Rothwell NJ \& Stock MJ (1983). Protein synthesis in liver, skeletal muscle and brown adipose tissue of rats fed a protein-deficient diet. Bioscience Reports, 3: 569-573.

22. Waterlow JC, Garlick PJ \& Millward DJ (1978). Protein Turnover in Mammalian Tissues and in the Whole Body. North Holland Publishing Company, Amsterdam.

23. Crowe PJ \& Royle GT (1988). Glucose kinetics in protein depletion effect of glucose infusion in the fasted rat. Journal of Nutrition, 118: 1240-1244. 